Supplemental digital content for Lanken PN, Novack DH, Daetwyler C, et al. Efficacy of an internet-based learning module and small-group debriefing on trainees' attitudes and communication skills toward patients with substance use disorders: results of a cluster randomized controlled trial. Acad Med.

Table of Contents

2 Supplemental Digital Appendix 1: Pre-Survey for Resident Physicians

11 Supplemental Digital Appendix 2: Facilitator's Guide to Debriefing Sessions For Medical Students and Residents

15 Supplemental Digital Appendix 3: Detailed Study Protocol and Schedule of Events for Residents

18 Supplemental Digital Appendix 4: Scoring Guide for NIDA Standardized Patient Content Checklist

21 Supplemental Digital Appendix 5: Pre-Survey for Medical Students

30 Supplemental Digital Figure 1: Modified CONSORT flow diagram of study population of resident physicians

31 Supplemental Digital Figure 2: Modified CONSORT flow diagram of study population of medical students

32 Supplemental Digital Table 1: Table of 7 Survey Factors Used as Outcome Variables and their Associated Survey Items with Factor Loading

33 Supplemental Digital Table 2: Resident Physicians Who Were Enrolled in Study from August 2011 to June 2012: Baseline Characteristics of Study Population in Intervention and Control Groups

35 Supplemental Digital Table 3: Medical Students Who Were Enrolled in Study from August 2011 to June 2012: Baseline Characteristics of Study Population in Intervention and Control Groups

Supplemental Digital Appendices 1 and 5

Copyright (C) 2014 University of Pennsylvania and Drexel University. Permission is granted to reproduce and use, with attribution, for educational and research purposes.

Supplemental Digital Appendices 2 and 4.

Copyright (C) 2014 Drexel University. Permission is granted to reproduce and use, with attribution, for educational and research purposes.

Supplemental Digital Appendix 3, Figures 1-2 and Tables 1-3

Copyright (C) Association of American Medical Colleges. All rights reserved. 


\section{Supplemental Digital Appendix 1: Pre-Survey for Resident Physicians}

I. The following questions ask about background information. Please answer the following questions about yourself. For each question, please select the single best answer unless otherwise indicated.

1. Sex:

2. Age:

3. Ethnicity:

4. Race: (select one or more)

a. American Indian or Alaska Native

b. Asian

c. Black/African American

d. Native Hawaiian or Other Pacific Islander

e. White

5. Year in Training:

9. What is your residency program?

6. What year did you start medical school?

7. What year did you graduate medical school?

8. What is your residency program's medical school affiliation:

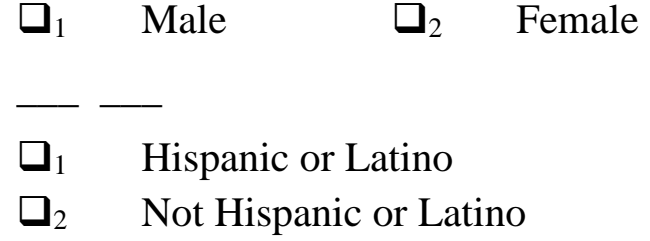

$\square_{1}$ Yes

$\square_{1}$ Yes

$\square_{1}$ Yes

$\square_{1}$ Yes

1 Yes

$\square_{1}$ PGY1

2 PGY2

PGY3

PGY4

$\square_{1}$ Drexel University College of Medicine

$\square_{2}$ University of Pennsylvania School of Medicine

$\square_{1}$ Family Medicine

Internal Medicine Categorical (non-Primary Care track)

$\square_{3}$ Internal Medicine-Pediatrics

$\square_{4}$ Internal Medicine Primary Care track

10. If you selected Internal Medicine

$\square_{1}$ Primary Care

Categorical (non-Primary Care track) in \# 9 above, what type of internal medicine do you intend to practice:

$\square_{2}$ Undecided

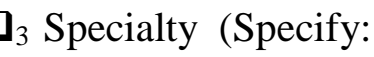

Public reporting time for this collection is estimated to average 10 minutes, including time for reviewing instructions, searching existing data sources, gathering and maintaining the data needed and completing and reviewing the collection of information. Send comments regarding this burden estimate or any other aspect of this collection of information, including suggestions for reducing this burden to NIDA OMB Officer, 6001 Executive Blvd., Bethesda, MD 20893. An agency may not conduct or sponsor, and a person is not required to respond to, a collection of information unless it displays a currently valid OMB control number. The OMB control number for this project is 0925-0635. 
For the remaining questions, please use these DEFINITIONS (from DSM-IV) for the following terms:

- Substance use disorders: consist of substance dependence and substance abuse disorders.

- Substance dependence can be characterized as a cluster of cognitive, behavioral, and psychological symptoms indicating that the individual continues use of the substance (e.g. illicit drug, prescription drugs, and other toxins) despite significant substance related problems (e.g. social, occupational). This can result in tolerance, withdrawal, and compulsive drug taking behavior).

- Substance abuse can be characterized as a maladaptive pattern of substance use manifested by recurrent and significant adverse consequences related to the repeated use of substances.

- Common synonyms: substance abuse, addiction, drug dependence, drug problem.

- Dual diagnosis: situation in which a patient suffers from both a mental disorder and a substance use disorder.

11. In medical school, how many hours of required formal instruction related to substance use disorders do you estimate that you had?
a. none
b. 1-3
c. $4-9$
d. $10-25$
e. $>25$

12. In residency to date, how many hours of formal instruction related to substance use disorders (e.g., Grand Rounds, Residents Report, M \& M, other formal didactics, etc) do you estimate you have had?
a. none
b. 1-3
c. 4-9
d. $10-25$
e. $>25$

II. For the following questions please choose the single best answer, considering the definitions provided above.

A. General Questions (Select the single best answer that is closest to your views)

1. How prepared do you think you are to discuss the following with your patients?

\begin{tabular}{|c|l|c|c|c|c|}
\hline & & $\begin{array}{c}\text { Very } \\
\text { Unprepared }\end{array}$ & $\begin{array}{c}\text { Somewhat } \\
\text { Unprepared }\end{array}$ & $\begin{array}{c}\text { Somewhat } \\
\text { Prepared }\end{array}$ & $\begin{array}{c}\text { Very } \\
\text { Prepared }\end{array}$ \\
\hline a. & Tobacco use & $\square_{1}$ & $\square_{2}$ & $\square_{3}$ & $\square_{4}$ \\
\hline b. & Alcohol abuse & $\square_{1}$ & $\square_{2}$ & $\square_{3}$ & $\square_{4}$ \\
\hline c. & Prescription drug abuse & $\square_{1}$ & $\square_{2}$ & $\square_{3}$ & $\square_{4}$ \\
\hline d. & Illicit drug use & $\square_{1}$ & $\square_{2}$ & $\square_{3}$ & $\square_{4}$ \\
\hline
\end{tabular}

2. How prepared do you think you are to provide counseling and initial treatment for patients about:

\begin{tabular}{|c|c|c|c|c|}
\hline & $\begin{array}{c}\text { Very } \\
\text { Unprepared }\end{array}$ & $\begin{array}{c}\text { Somewhat } \\
\text { Unprepared }\end{array}$ & $\begin{array}{c}\text { Somewhat } \\
\text { Prepared }\end{array}$ & $\begin{array}{c}\text { Very } \\
\text { Prepared }\end{array}$ \\
\cline { 1 - 2 } & $\square_{1}$ & $\square_{2}$ & $\square_{3}$ & $\square_{4}$ \\
\hline a. Tobacco use & $\square_{1}$ & $\square_{2}$ & $\square_{3}$ & $\square_{4}$ \\
\hline b. Alcohol abuse & Page 2 of 9 & & \multicolumn{2}{|c|}{ RESPRE } \\
\hline
\end{tabular}


Pre-Survey for Resident Physicians

\begin{tabular}{|l|c|c|c|c|}
\hline & $\begin{array}{c}\text { Very } \\
\text { Unprepared }\end{array}$ & $\begin{array}{c}\text { Somewhat } \\
\text { Unprepared }\end{array}$ & $\begin{array}{c}\text { Somewhat } \\
\text { Prepared }\end{array}$ & $\begin{array}{c}\text { Very } \\
\text { Prepared }\end{array}$ \\
\cline { 2 - 3 } & $\square_{1}$ & $\square_{2}$ & $\square_{3}$ & $\square_{4}$ \\
\hline c. Prescription drug abuse & $\square_{1}$ & $\square_{2}$ & $\square_{3}$ & $\square_{4}$ \\
\hline d. Illicit drug use & $\square_{1}$ & $\square_{2}$ & $\square_{3}$ & $\square_{4}$ \\
\hline $\begin{array}{l}\text { e. Management of chronic } \\
\text { pain }\end{array}$ & & $\square_{n}$ & & \\
\hline
\end{tabular}

3. How important is it for physicians to be skilled at screening patients for substance use disorders?

Not at all

Important

Somewhat

口 12

$\square$
3

$\square$

Important

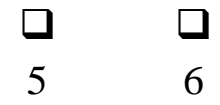

Extremely

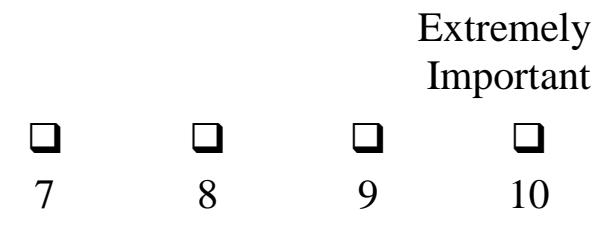

4. How important is it for physicians to be skilled at providing counseling and initial treatment to patients with substance use disorders?

Not at all

Important

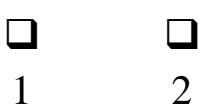

Somewhat

Important
Extremely

Important

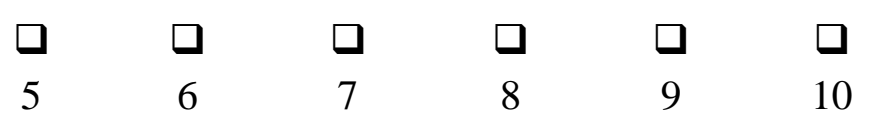

5. How confident are you in your knowledge of substance use disorders?

Not at all

Confident

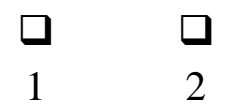

Somewhat

Confident
Extremely

Confident

6. How confident are you in your ability to screen patients for substance use disorders?

Not at all

Confident
Somewhat

Confident
Extremely

Confident

$\begin{array}{cccccccccc}\square & \square & \square & \square & \square & \square & \square & \square & \square & \square \\ 1 & 2 & 3 & 4 & 5 & 6 & 7 & 8 & 9 & 10\end{array}$

7. How confident are you in your ability to provide counseling and initial treatment to patients with substance use disorders?

Not at all

Confident
Somewhat

Confident

Extremely

Confident 


\title{
Pre-Survey for Resident Physicians
}

8. How confident are you that your counseling and other treatment will make a difference for your patients with a substance use disorder involving:

a. Tobacco use

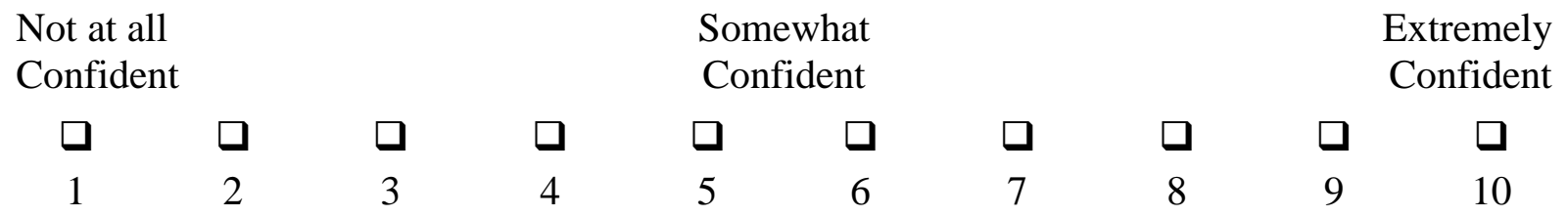

b. Alcohol abuse

Not at all

Confident

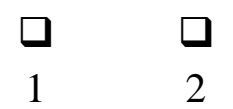

c. Prescription drug abuse

Not at all

Somewhat

Confident

$\begin{array}{llll}\square & \square & \square & \square \\ 1 & 2 & 3 & 4\end{array}$

d. Illicit drug use

Somewhat

Confident

Confident

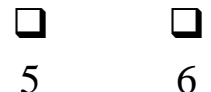

Somewhat

Confident

Confident

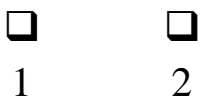

3

$\square$

$\begin{array}{ll}\square & \square \\ 5 & 6\end{array}$

$\square$

$\square$

Extremely

Confident

Extremely

Confident

10

\author{
(2)
}




\section{Pre-Survey for Resident Physicians}

B. Please rate your current skill level for the following:

\begin{tabular}{|l|c|c|c|c|}
\hline & $\begin{array}{c}\text { Not at } \\
\text { all } \\
\text { skilled }\end{array}$ & $\begin{array}{c}\text { Somewhat } \\
\text { Skilled }\end{array}$ & $\begin{array}{c}\text { Moderately } \\
\text { Skilled }\end{array}$ & $\begin{array}{c}\text { Very } \\
\text { Skilled }\end{array}$ \\
\hline 1. Screen for substance use disorders & $\square_{1}$ & $\square_{2}$ & $\square_{3}$ & $\square_{4}$ \\
\hline 2. Diagnose substance use disorders & $\square_{1}$ & $\square_{2}$ & $\square_{3}$ & $\square_{4}$ \\
\hline 3. Diagnose "Dual - Diagnosis" patients & $\square_{1}$ & $\square_{2}$ & $\square_{3}$ & $\square_{4}$ \\
\hline 4. Treat substance use disorders & $\square_{1}$ & $\square_{2}$ & $\square_{3}$ & $\square_{4}$ \\
\hline 5. Treat "Dual - Diagnosis" patients & $\square_{1}$ & $\square_{2}$ & $\square_{3}$ & $\square_{4}$ \\
\hline 6. Refer patients with substance use disorders & $\square_{1}$ & $\square_{2}$ & $\square_{3}$ & $\square_{4}$ \\
\hline
\end{tabular}

C. How well do you understand:

\begin{tabular}{|l|c|c|c|c|}
\hline & $\begin{array}{c}\text { Not at } \\
\text { all }\end{array}$ & Somewhat & Moderately & $\begin{array}{c}\text { Very } \\
\text { Well }\end{array}$ \\
\hline 1. The workings of 12-step programs & $\square_{1}$ & $\square_{2}$ & $\square_{3}$ & $\square_{4}$ \\
\hline $\begin{array}{l}\text { 2. Pharmacotherapies for treating and } \\
\text { preventing the relapse of substance use } \\
\text { disorders. }\end{array}$ & $\square_{1}$ & $\square_{2}$ & $\square_{3}$ & $\square_{4}$ \\
\hline $\begin{array}{l}\text { 3. Various forms of therapeutic intervention } \\
\text { programs used in substance abuse treatment }\end{array}$ & $\square_{1}$ & $\square_{2}$ & $\square_{3}$ & $\square_{4}$ \\
\hline 4. Relapse prevention & $\square_{1}$ & $\square_{2}$ & $\square_{3}$ & $\square_{4}$ \\
\hline
\end{tabular}




\section{Pre-Survey for Resident Physicians}

III. The following questions address your personal views regarding patients with substance use disorders. Please select one answer that is closest to your views.

Strongly

Disagree

Disagree

Strongly

1. These patients over utilize healthcare resources and provide nothing in return

2. Physicians who diagnose drug addiction early improve the chance of treatment success

3. Drug addiction is a treatable illness

4. A drug-dependent person who has relapsed several times probably cannot be successfully treated

5. Most drug-dependent persons are unpleasant to work with as patients

6. A drug-dependent person cannot be helped until he/she has hit "rock bottom"

7. The care of other patients suffers because of time and resources spent on these patients

8. Family involvement is a very important part of the treatment of drug addiction

9. At the core of substance abuse is a failure to exercise self control

10. My feelings of disapproval of substance abusers get in the way of my ability to empathize with them

11. I can make a great difference in the lives of my patients who abuse drugs

12. People who abuse drugs have a special ability to manipulate physicians

13. Treatment is effective and worth the effort

\begin{tabular}{|c|c|c|}
\hline$\square_{1}$ & $\square_{2}$ & $\square_{3}$ \\
\hline
\end{tabular}

\begin{tabular}{|c|c|c|c|}
\hline$\square_{1}$ & $\square_{2}$ & $\square_{3}$ & $\square_{4}$ \\
\hline$\square_{1}$ & $\square_{2}$ & $\square_{3}$ & $\square_{4}$ \\
\hline$\square_{1}$ & $\square_{2}$ & $\square_{3}$ & $\square_{4}$ \\
\hline
\end{tabular}

\begin{tabular}{|c|c|c|c|}
\hline$\square_{1}$ & $\square_{2}$ & $\square_{3}$ & $\square_{4}$ \\
\hline$\square_{1}$ & $\square_{2}$ & $\square_{3}$ & $\square_{4}$ \\
\hline$\square_{1}$ & $\square_{2}$ & $\square_{3}$ & $\square_{4}$ \\
\hline$\square_{1}$ & $\square_{2}$ & $\square_{3}$ & $\square_{4}$ \\
\hline$\square_{1}$ & $\square_{2}$ & $\square_{3}$ & $\square_{4}$ \\
\hline$\square_{1}$ & $\square_{2}$ & $\square_{3}$ & $\square_{4}$ \\
\hline$\square_{1}$ & $\square_{2}$ & $\square_{3}$ & $\square_{4}$ \\
\hline$\square_{1}$ & $\square_{2}$ & $\square_{3}$ & $\square_{4}$ \\
\hline$\square_{1}$ & $\square_{2}$ & $\square_{3}$ & $\square_{4}$ \\
\hline
\end{tabular}




\section{Pre-Survey for Resident Physicians}

\section{Additional Questions}

1. Have you ever attended a 12-Step meeting as either a participant or an observer?

$\square_{1}$ Yes $\quad \square_{0}$ No

2. If your answer to Question IV.1 is "Yes," were you required to observe a 12-step meeting:

(Skip this question if your answer to Question IV.1 is "No")?

a. As part of a medical school course

$\square_{1}$ Yes $\square_{0}$ No

b. As part of your residency training program

$\square_{1}$ Yes $\square_{0}$ No

3. Do you have a history of past or current substance abuse or dependence (alcohol or other drugs [excluding nicotine]) OR do you have a close friend or family

$\square_{1}$ Yes $\quad \square_{0}$ No member or colleague with such a history?

4. Some physicians have negative attitudes towards patients with substance use disorders. What do you think are the sources of those attitudes? (Number each source below from 1-5 where "1" signifies the most important source of the negative attitude, " 2 " the 2 nd most important source, and so on; use each number only once)

\begin{tabular}{|c|c|c|c|c|c|c|}
\hline a. & $\begin{array}{l}\text { Negative experiences with patients with } \\
\text { substance use disorders }\end{array}$ & $\square 1$ & $\square 2$ & $\square 3$ & $\square 4$ & $\square 5$ \\
\hline b. & $\begin{array}{l}\text { Substance use by self, family member or } \\
\text { close friend }\end{array}$ & $\square 1$ & $\square 2$ & $\square 3$ & $\square 4$ & $\square 5$ \\
\hline c. & Attending physicians with negative attitudes & $\square 1$ & $\square 2$ & $\square 3$ & $\square 4$ & $\square 5$ \\
\hline d. & $\begin{array}{l}\text { Other resident physicians with negative } \\
\text { attitudes }\end{array}$ & $\square 1$ & $\square 2$ & $\square 3$ & $\square 4$ & $\square 5$ \\
\hline e. & $\begin{array}{l}\text { Non-physician health care professionals, } \\
\text { e.g., nurses, with negative attitudes }\end{array}$ & $\square 1$ & $\square 2$ & $\square 3$ & $\square 4$ & $\square 5$ \\
\hline
\end{tabular}

5. Some physicians have positive attitudes towards patients with substance use disorders. What do you think are the sources of those attitudes? (Number each source below from 1-5 where "1" signifies the most important source of the positive attitude, "2" the 2 nd most important source, and so on; use each number only once)

\begin{tabular}{|c|c|c|c|c|c|c|}
\hline a. & $\begin{array}{l}\text { Positive experience with patients with } \\
\text { substance use disorders }\end{array}$ & $\square 1$ & $\square 2$ & $\square 3$ & $\square 4$ & $\square 5$ \\
\hline b. & $\begin{array}{l}\text { Substance use by self, family member or close } \\
\text { friend }\end{array}$ & $\square 1$ & $\square 2$ & $\square 3$ & $\square 4$ & $\square 5$ \\
\hline c. & Attending physicians with positive attitudes & $\square 1$ & $\square 2$ & $\square 3$ & $\square 4$ & $\square 5$ \\
\hline $\mathrm{d}$. & $\begin{array}{l}\text { Other resident physicians with positive } \\
\text { attitudes }\end{array}$ & $\square 1$ & $\square 2$ & $\square 3$ & $\square 4$ & $\square 5$ \\
\hline e. & $\begin{array}{l}\text { Non-physician health care professionals, e.g., } \\
\text { nurses, with positive attitudes }\end{array}$ & $\square 1$ & $\square 2$ & $\square 3$ & $\square 4$ & $\square 5$ \\
\hline
\end{tabular}




\section{Pre-Survey for Resident Physicians}

V. Jefferson Scale of Physician Empathy (JSPE)*.Instructions: Please indicate the extent of your agreement or disagreement with each of the following statements by checking the box with the appropriate rating. Please use the following 7-point scale (a higher number on the scale

indicates more agreement).

0------1-------2-------3-------4-------5-------6

\section{Strongly Disagree Strongly Agree}

\section{Strongly}

Disagree

Strongly

Agree

1. Physicians' understanding of their patients' feelings and the feelings of their patients' families does not influence medical or surgical treatment.

2. Patients feel better when their physicians understand their feelings.

3. It is difficult for a physician to view things from patients' perspectives.

4. Understanding body language is as important as verbal communication in physician-patient relationships.

5. A physician's sense of humor contributes to a better clinical outcome.

6. Because people are different, it is difficult to see things from patients' perspectives.

7. Attention to patients' emotions is not important in history taking.

8. Attentiveness to patients' personal experiences does not influence treatment outcomes.

9. Physicians should try to stand in their patients' shoes when providing care to them.

10. Patients value a physician's understanding of their feelings which is therapeutic in its own right.

11. Patients' illnesses can be cured only by medical or surgical treatment; therefore, physicians' emotional ties with their patients do not have a significant influence in medical or surgical treatment.

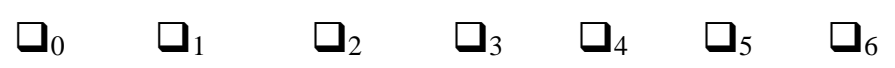

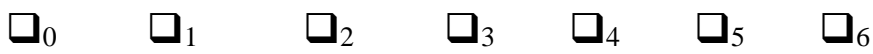

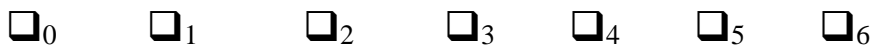

$\square_{0}$

$\square_{2}$

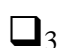

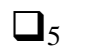
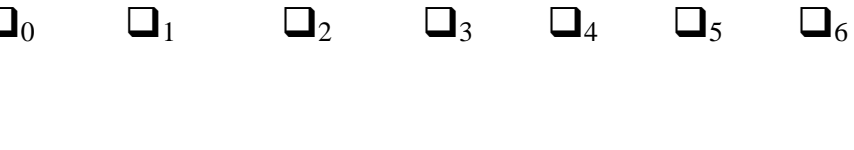

$\square_{0}$

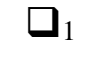

$\square_{2}$<smiles></smiles><smiles>[GeH3]</smiles><smiles>[AsH2]</smiles><smiles>[124OH]</smiles>

\section{$\square_{0}$}

$\square_{1}$

$\square_{2}$

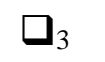

$\square_{4}$

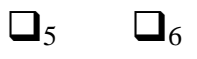

$\square_{0}$

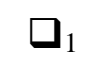

$\square_{2}$

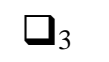

$\square_{4}$

$\square_{5}$

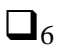

\section{tre}


12. Asking patients about what is happening in their personal lives is not helpful in understanding their physical complaints.

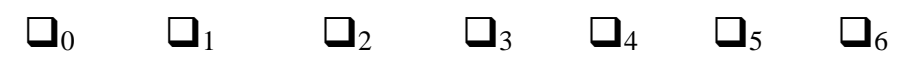

13. Physicians should try to understand what is going on in their patients' minds by paying attention to their non-verbal cues and body language.

14. I believe that emotion has no place in the treatment of medical illness.

15. Empathy is a therapeutic skill without which the physician's success is limited.<smiles>[AlH2]</smiles>

$\sqrt{2}$

6. Physicians' understanding of the emotional status of their patients and their families is one important component of the physician-patient relationship.

17. Physicians should try to think like their patients in order to render better care.

18. Physicians should not allow themselves to be influenced by strong personal bonds between their patients and their family members.

19. I do not enjoy reading non-medical literature or the arts.

20. I believe that empathy is an important therapeutic factor in medical treatment.

*Used with permission from Jefferson Medical College. All rights reserved. 


\section{Supplemental Digital Appendix 2: Facilitator's Guide to Debriefing Sessions For Medical Students and Residents}

\section{Debriefing Duration: \\ Students: $\sim 50-60 \mathrm{~min}$ (up to $\max$ of $60 \mathrm{~min}$ ) \\ Residents: $\sim 50-60 \mathrm{~min}$ (up to $\mathrm{max}$ of $75 \mathrm{~min}$ ) but be sure that there are 10 minutes available at the end of the allotted time for the residents to complete 10 min Post-Survey 1.}

The following is a suggested format that may be adjusted depending on the experience and level of training of your learners. These guidelines assume that the learners have viewed the module ahead of time (learners who haven't viewed the module should be identified as such but will be allowed to attend the Debriefing and take the Post-Survey). All learners should have completed the Self-Reflection Questions that are located near the beginning of the Module. These instructions and recommendations should be adapted for virtual debriefings (DUCOM students at certain remote sites).

To prepare for this session, you should read this Facilitator's Guide (10-15 min) and then:

1) View the online module in its entirety (up to 2-3 hours if you haven't viewed it before or

2) Review the online module's learning objectives, content, organization and interviews, especially the interviews of patients who were substance abusers and are in recovery ( 15-30 min).

3) Ask your local Research Project Manager or Investigator if you have questions or don't have all of the materials mentioned below. The Research Project Managers are Felecia Myers for DUCOM and Sandra Kaplan for Penn Med.

At the Start of the Session: (Written materials that are mentioned below should be in the Debriefing packet that your local Research Coordinator should provide to you at or before the start of the Debriefing session)

1. Take attendance (and note who is present or absent on the list of students/residents).

2. Pass out the anonymous 5-question sheets (one per learner).

3. Ask your learners to take a few minutes to indicate their responses to the 5 questions. (THEY SHOULD NOT PUT THEIR NAMES ON THESE SHEETS)

4. Ask them to turn in the responses and randomly stack them in a pile near you.

Discuss the main goals of this session: To reinforce what was presented in the doc.com module, whose goals are:

- To enhance learners' understanding and skills in screening and counseling patients with substance use disorders.

- To enhance their attitudes so that they will regard these patients as having a chronic disease that they can treat with empathy and compassion.

\section{Ask your learners if they agree with working on these goals.}

\section{Discussion (20 minutes)}

Summarize replies to the attitude questions you've just collected, and then go over learners' replies to 5Question Sheets. Be sure to highlight how physician attitudes might affect care. Ask how your learners developed their attitudes toward patients with substance use/abuse problems. Ask who has compassion for patients with substance abuse problems, and how and why they have that compassion. (Sometimes a 
poignant story told by a co-resident can have great impact on the group.)

Ask your learners about their experiences with patients who have had problems with substance use or abuse.

- What was the nature of the interaction?

- How did the patient make you feel?

- How did your feelings about the patient affect your care of him or her?

- What did you do/say that was helpful or not?

- What was the outcome of the interaction?

- In retrospect, what would you change about the interaction?

If you are working with a small group, ask each member of the group about his or her experiences. If you are working with a large group, ask trainees to turn to each other in groups of two or three and describe their experiences for 5 to 10 minutes. Afterwards ask each group to contribute the essential points about their experiences in working with substance using patients.

\section{Understanding Addiction as a Disease 5-10 minutes}

Ask your learners about their understanding of the nature of addiction. They should understand addiction as a brain disease with behavioral features that has genetic, developmental and environmental underpinnings. If your learners have not had a robust background in the scientific evidence on the biology of substance abuse, or if the majority of them have indicated they do not believe that substance abuse disorders are a disease process, you should emphasize some main points:

\section{Addiction is A Brain Disease Characterized by:}

- Compulsive Behavior

- Continued abuse of drugs (substances) despite negative consequences (on their social relationsh occupation, and physical and emotional health)

- Persistent changes in the brain's structure and function

\section{Addiction is Similar to Other Chronic Illnesses Because:}

- It has biological and behavioral components, both of which must be addressed during treatment.

- Recovery from it--protracted abstinence and restored functioning--is often a long-term process requiring repeated episodes of treatment.

- Relapses can occur during or after treatment, and signal a need for treatment adjustment or reinstatement.

- Participation in support programs during and following treatment can be helpful in sustaining long-term recovery

\section{Lessons from the Module (15 minutes)}

Ask learners what were the main lessons they learned from the module about screening and initial counseling. What questions do they have after reading/viewing the module? If many learners express discouragement or cynicism about caring for patients with substance use/abuse disorders, ask who has had positive experiences in which their intervention has let to a patient becoming sober. If none of the learners has a success story or after hearing the about learners' experiences, you should refer to the 
patients in the patient interview section at the end of the module. These are people who were actively addicted, and who are now sober and leading productive lives, in some cases 15 years later. Why do the learners think that these 5 people volunteered to be interviewed for this online module without disguising their name, voice or appearance? Emphasize that many people can achieve sobriety. Substance abuse is a severe chronic disease with frequent relapses and substantial morbidity and mortality. But about $30 \%$ who enter treatment programs are abstinent up to 20 years later often after going through many rehab programs. (1)

Learners should be left with some important lessons related to their attitudes:

- That if they feel themselves being annoyed or judgmental about a patient with substance abuse issues, they should step back from that, since negative judgments will often negatively impact their care. They can remind themselves that this is a disease like any other, and that these patients have often had difficult developmental, family, and cultural experiences, and a genetic predisposition that contributed toward their condition, and that they are just as deserving of compassion as any patient.

- That the physician should never give up on their patients with these problems. It is a chronic, relapsing disease, but many patients achieve sobriety, sometimes after many attempts. And that sobriety brings positive changes not only the patients but also their families and communities. If the physician maintains patience, hope and optimism, the patient will be encouraged to keep working toward sobriety.

Give out and go over the Handout: Essentials of Screening and Initial Counseling: Ask-Tell-Ask (in the Debriefing packet). If a resident/student has difficulty with finding the right words to say to a patient, or how to say something to a patient just diagnosed with a substance use/abuse disorder, you might do a mini-role play where you play the patient, and the resident tells you, for example, that he/she thinks you have a substance dependence problem.

\section{Wrap Up (10 minutes)}

If you are teaching a small group, go around the room and ask each person what they learned that they will use in their future work with patients. If you are working with a large group, ask learners to turn to their neighbors to tell them what they have learned. Then ask people to volunteer some of the best lessons learned.

If there is time, ask the learners for feedback, and how in the future you might help learners achieve the goals of this debriefing session.

At the End of the Residents' Debriefing: Ask residents to stay for $\sim 10$ more minutes

- Give out the Post-Survey 1 booklets for Residents (in your Debriefing packet)

- Ask them to write their Resident Tracking Number at the top of the first page.

\section{References:}

1. Scherbaum N, Specka M: Factors influencing the course of opiate addiction. Int. J. Methods Psychiatr. Res. 17(S1): S39-S44 (2008) 


\section{Handout: Essentials of the Screening and Initial Counseling : Ask-Tell-Ask}

\section{ASK:}

1. Ask all patients if they use or have used alcohol or other drugs, including prescription pain medication. Screen all patients for past and present substance use.

2. If any use, ask CAGE questions for alcohol/drugs or use NIDA modified ASSIST questionnaire If one or more CAGE questions are positive:

3. Ask about frequency of use and method of administration

4. Ask patients how they acquire their substances, including how they can afford them.

5. Ask patients about the current and potential consequences of their substance use.

6. Ask about past attempts to quit or cut down; any withdrawal symptoms, how long abstinent, etc.

7. Ask about current mood and any past mental health problems.

8. Assess patients' conviction whether their drug use is problematic, and confidence about their ability to quit using.

9. Ask patients if they are open to hearing that the assessment might indicate a substance use problem and a need for specific help.

10. Conduct your interview in a non-judgmental way. (For example, do not use phrases such as, "This is really a will-power problem and you need to just quit!" or any statement that might induce judgment or shame.)

\section{TELL:}

1. Tell patients of your concern that they have a substance use problem, and need help for that. Talk about the negative impact of substance use on patients' health, family, employment, mental health and well-being.

2. Speak clearly and succinctly about treatment options: stopping on their own, joining a 12-step program, going to an addiction specialist, and/or being referred to a treatment center.

3. If you plan to continue prescribing narcotics (opioids) for the patient, initiate a treatment contract.

4. Inform patients about the role of drug and/or alcohol testing for treatment monitoring.

5. State your willingness to provide continuing care to patients who abuse substances.

6. Communicate that individual needs vary, and treatment consists of psychological, social, vocational, and biological interventions.

7. Make a supportive statement like, "Recovery is a long-term process and it often takes years to return to fully responsible functioning."

8. Offer to communicate with patients' families.

\section{ASK}

1. Ask patients if they are ready to accept a referral to treatment.

2. Ask patients about their reactions to the discussion.

3. Ask patients about their questions and concerns. 


\section{Supplemental Digital Appendix 3: Detailed Study Protocol and Schedule of}

\section{Events for Residents}

On or close to the first day of a rotation, we informed residents about the study and invited them to participate. Immediately after giving informed consent, participating residents completed the baseline pre-survey (Pre-Survey for Residents, Supplemental Digital Content [SDC] Appendix 1). Both pre- and post-surveys were administered in a paper booklet format.

Two to 7 days after enrollment, subjects in both the intervention (I-group) and the control group (C-group) did a 20 minute baseline interview of a standardized patient (SP) with a substance use disorder (SUD) (Case 1) that we created for this study. This was a live internet-based interview performed via videoconference. ${ }^{1,2}$ Residents did not receive feedback about their interview during or after their first interview. We used a 23-item checklist to assess performance (SDC Appendix 4) of an individual resident's performance on a single station SP interview before and after the intervention in the I-group compared to those in the C-group. See Methods for details of scoring SP interviews.

After all of the residents in a given cluster completed their pre-surveys and first SP interviews, we disclosed their cluster randomization to them. We emailed those in the I-group a unique randomly generated password and hyperlink to access a website for the internet-based learning (IBL) module that was used exclusively for this study (but otherwise identical to NIDAsupported module in the public domain). ${ }^{3-5}$ We instructed residents to spend at least one hour visiting the restricted access module in a self-directed manner, i.e., to visit web pages of the module based on their own training needs assessment. We also asked them to complete one or more self-reflection questions that were included within the module. 
Access to the module was open for 5 to 7 days prior to the debriefing and closed by midnight on the evening before the debriefing (held during the second week of their rotations). We confirmed that I-group subjects had logged onto the module and also recorded their time of $\log$ in(s) and $\log$ off(s) as well as time on and off for individual pages and videos played.

On the morning of the scheduled debriefing, we downloaded the residents' answers to these questions and emailed them without personal identifying information to the debriefing's facilitator to help to guide the debriefing's discussion. Residents in the I-group had 60 to 75 minute long debriefings. One of the investigators (DHN) had trained six primary care physicians in the briefing's format and had provided a written facilitator's guide to follow (see SDC Appendix 2). One faculty member facilitated each debriefing. At the end of the debriefing, the residents in the I-group completed their post-surveys. Residents in the C-group completed their post-surveys on approximately the same day of their rotation as the I-group residents.

Two to 7 days after completing the post-survey, residents in both I- and C-groups did a second 20 minute interview of a different SP with a SUD (Case 2). Immediately after their interview, the SP gave the residents feedback about their performance. Both Case 1 and 2 were developed by the investigators for use in this study.

\section{References}

1. Novack DH, Cohen D, Peitzman SJ, Beadenkopf S, Gracely E, Morris J. A pilot test of WebOSCE: a system for assessing trainees' clinical skills via teleconference. Med Teach. 2002;24:483-487.

2. Clever SL, Novack DH, Cohen DG, Levinson W. Evaluating surgeons' informed decision making skills: pilot test using a videoconferenced standardised patient. Med Educ. 2003;37:1094-1099. 
3. Daetwyler CJ, Schindler BA, Parran T. The Clinical Assessment of Substance Use Disorders. MedEdPORTAL; 2012. Available from: https://www.mededportal.org/publication/9110. 4. Schindler BA, Parran T. DEMO module 30: The Clinical Assessment of Substance Use Disorders. (http://webcampus.drexelmed.edu/doccom/user/). Revised October 14, 2011. Accessed December 19, 2013.

5. The National Institute on Drug Abuse (NIDA) Centers of Excellence (CoE) for Physician Information. (http://www.drugabuse.gov/nidamed/centers-excellence). Revised June 2012. Accessed December 19, 2013. 


\section{Supplemental Digital Appendix 4: Scoring Guide for NIDA Standardized Patient Content Checklist}

ASK:

1. Asks me about past and present substance use (prescription meds and/or illicit substances - other than alcohol).

Score: 0 - not asked about any substance use, 1 -only asked about past OR present use, 2 -asked about past AND present substance use

2. Asks me about past and present use of alcohol.

Score: 0-not asked about any alcohol use, 1- only asked about alcohol use in the past OR present, 2 asked about past $A N D$ present alcohol use

3. If any use, asks CAGE questions for alcohol/drugs or use NIDA modified ASSIST questionnaire:

*CAGE Questions: 1. Have you tried to cut down? 2. Have people got on you about use? 3. Do you feel guilty about alcohol/drug use? 4. Ever need to use first thing in the AM?

Score: 0 - not asked any CAGE questions, 1 -only asked ONE CAGE question, 2 - only asked TWO CAGE questions, 3 - asked only THREE CAGE questions, 4 -asked all FOUR CAGE questions

4. Asks about frequency of use.

Score: 0 - not asked about frequency, 1 - asked how often using substance

5. Asks about method of administration.

Score: 0 - not asked how substance is taken, 1 -asked how substance is taken

6. Asks me for my perspective on the current and potential consequences of my drug use.

Score: 0 - not asked for my perspective on my drug use, 1 -asked for my perspective about current $O R$ future consequences of drug use, 2 - asked for my perspective about current $A N D$ future consequences of drug use

7. Asks me how I acquire my substances - including how I can afford them.

Score: 0 - not asked how substances are acquired, 1 -asked how substances are obtained $O R$ how substances are paid for, 2 - asked how substances are obtained AND how they are paid for

8. Asks about past quit attempts, or attempts to cut down, withdrawal symptoms, how long abstinent, etc. 
Score: 0 - not asked about past attempts to quit, 1 - asked about any past attempts to quit OR if ever tried to cut down use OR how you felt when didn't have substance, 2 - asked about past attempts to quit AND at least 1 follow-up question about what happened (i.e., withdrawal symptoms, how long abstinent, etc.)

9. Asks about current mood and any past mental health problems.

Score: 0 - not asked about current mood, 1-asked about current mood OR past mental health problems, 2 - asked about current mood AND past mental health problems

10. Asks me if I am open to hearing that I may have a substance abuse problem and need specific help for this.

Score: 0 - not asked if I am open to hearing that I may have a substance abuse problem, 1 -asked if I am open to hearing that I may have a problem AND need help for it

11. Conducts interview in a non-judgmental way.

(e.g., does not use phrases such as, "This is really a will-power problem and you need to just quit!" or any statement that might induce judgment or shame.)

Score: 0 - interview conducted in a judgmental way, 1-interview is conducted in a non-judgmental way

\section{TELL:}

12. Tells me that she/he is concerned that I have a substance abuse problem, and need help for that. Talks about the potential negative impact of substance use on my health, family, employment, mental health and well-being.

Score: 0 -not told that I have a substance abuse problem, 1 -told that I have a substance abuse problem and need help $O R$ if told current substance use could have negative impact on my life in some way, 2 - told that I have a substance abuse problem and need help AND told about the potential negative impact on my life

13. Speaks clearly and succinctly about treatment options and must mention at least 2 of the following: stopping on my own, join a 12-step program, go to an addiction specialist, and/or be referred to a treatment center.

Score: 0 - no mention of treatment options, 1- only mentioned/offered one treatment option, 2 offered at least two treatment options

14. Tells me that individual needs vary, and treatment consists of psychological, social, vocational, and biological interventions.

Score: 0 - not told that individual patient's need vary and not told that treatment consists of various interventions, 1- told that individual patient's needs vary OR that treatment consists of various interventions, 2 - told that individual patient's needs vary AND that treatment consists of various interventions

15. Discusses a treatment contract. 
Score: 0 - no discussion of treatment contract, 1 - treatment contract is discussed

16. Informs me about the role of drug and/or alcohol testing in treatment monitoring.

Score: 0 -not informed about the role of drug and/or alcohol testing as part of treatment monitoring, 1 - informed about the role of drug and/or alcohol testing as part of treatment monitoring

17. States his or her willingness to provide continuing care to me.

(e.g., "I want to continue seeing you and monitoring you during your rehab.")

Score: 0 - no statement regarding willingness to provide care is made, 1- some statement regarding willingness to provide care to patient is made

18. Makes a supportive statement.

(e.g., "Recovery is a long-term process and it often takes years to return to fully responsible functioning.")

Score: 0 - no supportive statement is made, 1 - some statement of support is made

19. Offers to communicate with my family.

Score: 0 -no offer to communicate with family is made, 1 - offer to communicate with family is made

ASK:

20. Assesses my conviction and confidence about my willingness to quit using.

(e.g., "How convinced are you that it's important to quit using? And how confident are you that you'll be able to quit?" [Using a scale of 1-10 or equivalent scale])

Score: 0 - my confidence and conviction are not asked about and gauged on a scale of 1-10, 1 - only my confidence OR conviction asked, 2 - both are asked

21. Asks me if I am ready to accept a referral to treatment.

Score: 0 - not asked if ready to accept referral for treatment, 1 - asked if ready to accept referral for treatment

22. Asks me about my reactions to the discussion.

Score: 0 - not asked about reaction to discussion, 1 - asked reaction to discussion

23. Asks me about my questions and/or concerns.

Score: 0 - not asked whether I have any questions and/or concerns, 1 - asked if I have any questions and/or concerns 
Date: $\bar{M} \frac{1}{\mathrm{D} D}-\frac{1}{\mathrm{YYY}} \overline{\mathrm{Y}}$

Please enter 6 digits ("4+2") above as follows: the last 4 digits of your Social Security number plus the 2 digit month of your birth, e.g., 08 for August
OMB No: 0925-0635

Expiration Date:

$07 / 31 / 2013$

\section{Supplemental Digital Appendix 5: Pre-Survey 2 for Medical Students}

I. The following questions ask about background information. Please answer the following questions about yourself. For each question, please select the single best answer unless otherwise indicated.

1. Sex:

2. Age:

3. Ethnicity:

4. Race: (select one or more)

a. American Indian or Alaska Native

b. Asian

c. Black/African American

d. Native Hawaiian or Other Pacific Islander

e. White

5. Year in Training:

9. Future Career Specialty

6. What year did you start medical school?

7. Anticipated year of medical school completion:

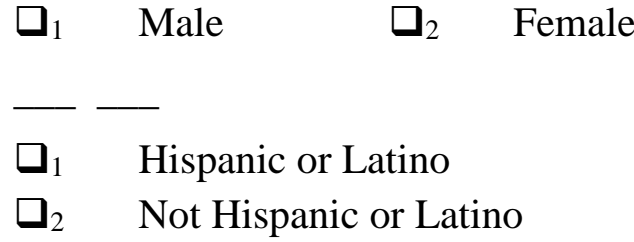

$\square_{1}$ Yes

$\square_{1}$ Yes

$\square_{1}$ Yes

$\square_{1}$ Yes

1 Yes

1 M1

$\square_{2} \mathrm{M} 2$

$\square_{3} \mathrm{M} 3$

$\square_{4}$ M4

8. Please check your medical school affiliation: $\square_{1}$ Drexel University College of Medicine $\square_{2}$ University of Pennsylvania School of Medicine
$\square_{1}$ Primary Care
$\square_{2}$ Undecided
3 Specialty (Specify: )

\footnotetext{
Public reporting time for this collection is estimated to average 10 minutes, including time for reviewing instructions, searching existing data sources, gathering and maintaining the data needed and completing and reviewing the collection of information. Send comments regarding this burden estimate or any other aspect of this collection of information, including suggestions for reducing this burden to NIDA OMB Officer, 6001 Executive Blvd., Bethesda, MD 20893. An agency may not conduct or sponsor, and a person is not required to respond to, a collection of information unless it displays a currently valid OMB control number. The OMB control number for this project is $0925-0635$.
} 
For the remaining questions, please use the provided definitions for the following terms: Substance use disorders: consist of substance dependence and substance abuse disorders.

Substance dependence can be characterized as a cluster of cognitive, behavioral, and psychological symptoms indicating that the individual continues use of the substance (e.g. illicit drug, prescription drugs, and other toxins) despite significant substance related problems (e.g. social, occupational). This can result in tolerance, withdrawal, and compulsive drug taking behavior).

Substance abuse can be characterized as a maladaptive pattern of substance use manifested by recurrent and significant adverse consequences related to the repeated use of substances.

Common synonyms: substance abuse, addiction, drug dependence, drug problem.

Dual diagnosis: situation in which a patient suffers from both a mental disorder and a substance use disorder.

10. In medical school to date, how many hours of required formal instruction related to substance use disorders do you estimate that you have had?
a. none
b. $1-3$
c. $4-9$
d. $10-25$
e. $>25$

11. During medical school to date, how many patients with medical problems and substance use disorders or substance use disorders alone have you personally helped to provide medical, psychiatric care, or surgical care?
a. none
b. 1-3
c. $4-9$
d. $10-25$
e. $>25$

II. For the following questions please choose the single best answer, considering the definitions provided above.

A. General Questions (Select the single best answer that is closest to your views)

1. How prepared do you think you are to discuss the following with your patients?

\begin{tabular}{|l|l|c|c|c|c|}
\hline & & $\begin{array}{c}\text { Very } \\
\text { Unprepared }\end{array}$ & $\begin{array}{c}\text { Somewhat } \\
\text { Unprepared }\end{array}$ & $\begin{array}{c}\text { Somewhat } \\
\text { Prepared }\end{array}$ & $\begin{array}{c}\text { Very } \\
\text { Prepared }\end{array}$ \\
\hline a. & Tobacco use & $\square_{1}$ & $\square_{2}$ & $\square_{3}$ & $\square_{4}$ \\
\hline b. & Alcohol abuse & $\square_{1}$ & $\square_{2}$ & $\square_{3}$ & $\square_{4}$ \\
\hline c. & Prescription drug abuse & $\square_{1}$ & $\square_{2}$ & $\square_{3}$ & $\square_{4}$ \\
\hline d. & Illicit drug use & $\square_{1}$ & $\square_{2}$ & $\square_{3}$ & $\square_{4}$ \\
\hline
\end{tabular}

2. How prepared do you think you are to provide counseling and initial treatment for patients about:

\begin{tabular}{c|c|c|c}
$\begin{array}{c}\text { Very } \\
\text { Unprepared }\end{array}$ & $\begin{array}{c}\text { Somewhat } \\
\text { Unprepared }\end{array}$ & $\begin{array}{c}\text { Somewhat } \\
\text { Prepared }\end{array}$ & $\begin{array}{c}\text { Very } \\
\text { Prepared }\end{array}$ \\
\cline { 1 - 2 } & &
\end{tabular}
a. Tobacco use
b. Alcohol abuse
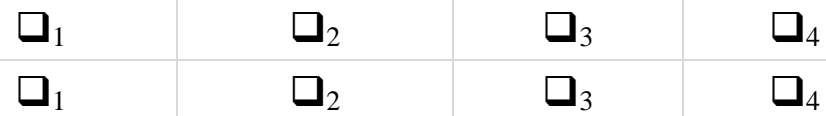
Pre-Survey 2 for Medical Students

\begin{tabular}{|l|c|c|c|c|}
\hline & $\begin{array}{c}\text { Very } \\
\text { Unprepared }\end{array}$ & $\begin{array}{c}\text { Somewhat } \\
\text { Unprepared }\end{array}$ & $\begin{array}{c}\text { Somewhat } \\
\text { Prepared }\end{array}$ & $\begin{array}{c}\text { Very } \\
\text { Prepared }\end{array}$ \\
\hline c. Prescription drug abuse & $\frac{\square_{1}}{\square_{2}}$ & $\square_{3}$ & $\square_{4}$ \\
\hline d. Illicit drug use & $\square_{1}$ & $\square_{2}$ & $\square_{3}$ & $\square_{4}$ \\
\hline $\begin{array}{l}\text { e. Management of chronic } \\
\text { pain }\end{array}$ & $\square_{1}$ & $\square_{2}$ & $\square_{3}$ & $\square_{4}$ \\
\hline
\end{tabular}

3. How important is it for physicians to be skilled at screening patients for substance use disorders?

Not at all

Important
Somewhat Important
Extremely

Important

$\begin{array}{llllllllll}\square & \square & \square & \square & \square & \square & \square & \square & \square & \square \\ 1 & 2 & 3 & 4 & 5 & 6 & 7 & 8 & 9 & 10\end{array}$

4. How important is it for physicians to be skilled at providing counseling and initial treatment to patients with substance use disorders?

Not at all

Important

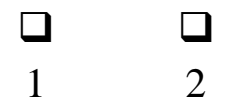

Somewhat

Important

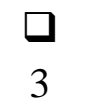

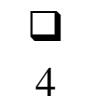

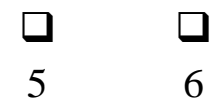

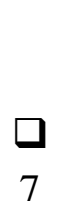

7
Extremely

Important

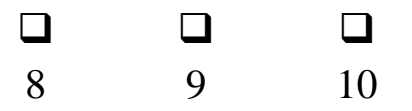

5. How confident are you in your knowledge of substance use disorders?
Not at all
Somewhat
Extremely
Confident
Confident
Confident
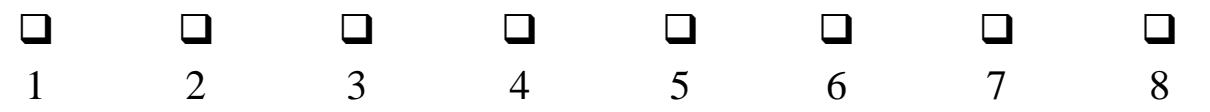
9
10

6. How confident are you in your ability to screen patients for substance use disorders?
Not at all
Somewhat
Extremely
Confident
Confident
Confident
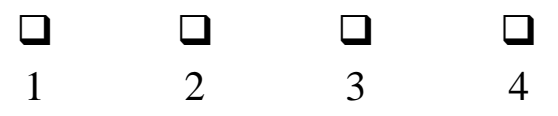
5
6

7
8
9
10

7. How confident are you in your ability to provide counseling and initial treatment to patients with substance use disorders?

Not at all

Confident

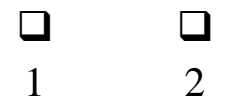

Somewhat

Confident

3

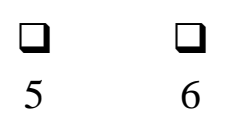

6
Extremely

Confident 


\section{Pre-Survey 2 for Medical Students}

8. How confident are you that your counseling and other treatment will make a difference for your patients with a substance use disorder involving:
a. Tobacco use

Not at all

Confident

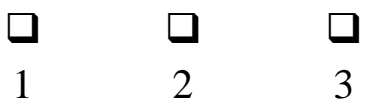

b. Alcohol abuse
Somewhat

Confident

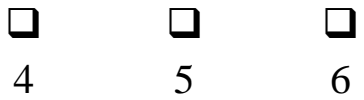

Extremely

Confident

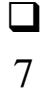

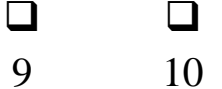

Not at all

Confident

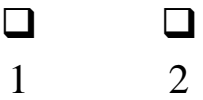

c. Prescription drug abuse
Somewhat

Confident

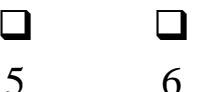

Extremely

Confident
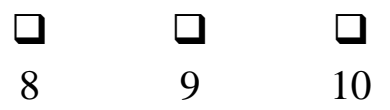

Not at all

Confident

1

2

Somewhat

Confident

d. Illicit drug use

Not at all

Confident

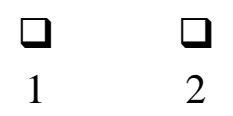

Somewhat Confident

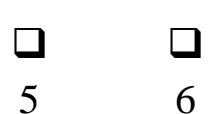

Extremely

Confident

56

$\square$

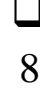

8

10

9. Where does your personal view of the practice of medicine lie on the spectrum between "medicine is a job" and a "medicine is a calling."

\begin{tabular}{|c|c|c|c|c|c|c|c|c|c|}
\hline $\begin{array}{l}100 \% \\
\text { "a job" }\end{array}$ & & & $\begin{array}{l}\text { ore " } \\
\text { that } \\
\text { calli }\end{array}$ & & & $\begin{array}{l}\text { More } \\
\text { allin } \\
\text { in "jo }\end{array}$ & & & $\begin{array}{l}100 \% \\
\text { alling" }\end{array}$ \\
\hline$\square$ & $\square$ & $\square$ & $\square$ & $\square$ & $\square$ & $\square$ & 口 & $\square$ & $\square$ \\
\hline 1 & 2 & 3 & 4 & 5 & 6 & 7 & 8 & 9 & 10 \\
\hline
\end{tabular}


Pre-Survey 2 for Medical Students

B. Please rate your current skill level for the following:

\begin{tabular}{|c|c|c|c|c|}
\hline & $\begin{array}{l}\text { Not at } \\
\text { all } \\
\text { skilled }\end{array}$ & $\begin{array}{l}\text { Somewhat } \\
\text { Skilled }\end{array}$ & $\begin{array}{l}\text { Moderately } \\
\text { Skilled }\end{array}$ & $\begin{array}{c}\text { Very } \\
\text { Skilled }\end{array}$ \\
\hline 1. Screen for substance use disorders & $\square_{1}$ & $\square_{2}$ & $\square_{3}$ & $\square_{4}$ \\
\hline 2. Diagnose substance use disorders & $\square_{1}$ & $\square_{2}$ & $\square_{3}$ & $\square_{4}$ \\
\hline 3. Diagnose "Dual - Diagnosis" patients & $\square_{1}$ & $\square_{2}$ & $\square_{3}$ & $\square_{4}$ \\
\hline 4. Treat substance use disorders & $\square_{1}$ & $\square_{2}$ & $\square_{3}$ & $\square_{4}$ \\
\hline 5. Treat "Dual - Diagnosis" patients & $\square_{1}$ & $\square_{2}$ & $\square_{3}$ & $\square_{4}$ \\
\hline $\begin{array}{l}\text { 6. Refer patients with substance use disorders } \\
\text { to other professionals for treatment }\end{array}$ & $\square_{1}$ & $\square_{2}$ & $\square_{3}$ & $\square_{4}$ \\
\hline \multicolumn{5}{|l|}{ C. How well do you understand: } \\
\hline & $\begin{array}{l}\text { Not at } \\
\text { all }\end{array}$ & Somewhat & Moderately & $\begin{array}{l}\text { Very } \\
\text { Well }\end{array}$ \\
\hline 1. The workings of 12 -step programs & $\square_{1}$ & $\square_{2}$ & $\square_{3}$ & $\square_{4}$ \\
\hline $\begin{array}{l}\text { 2. Pharmacotherapies for treating and } \\
\text { preventing the relapse of substance use } \\
\text { disorders. }\end{array}$ & $\square_{1}$ & $\square_{2}$ & $\square_{3}$ & $\square_{4}$ \\
\hline $\begin{array}{l}\text { 3. Various forms of therapeutic intervention } \\
\text { programs used in substance abuse treatment }\end{array}$ & $\square_{1}$ & $\square_{2}$ & $\square_{3}$ & $\square_{4}$ \\
\hline 4. Relapse prevention & $\square_{1}$ & $\square_{2}$ & $\square_{3}$ & $\square_{4}$ \\
\hline
\end{tabular}




\section{The following questions address your personal views regarding patients with substance use disorders. Please select one answer that is closest to your views.}

\section{Strongly \\ Disagree}

1. These patients over utilize healthcare resources and provide nothing in return

2. Physicians who diagnose drug addiction early improve the chance of treatment success

3. Drug addiction is a treatable illness

4. A drug-dependent person who has relapsed several times probably cannot be successfully treated

5. Most drug-dependent persons are unpleasant to work with as patients

6. A drug-dependent person cannot be helped until he/she has hit "rock bottom"

7. The care of other patients suffers because of time and resources spent on these patients

8. Family involvement is a very important part of the treatment of drug addiction

9. At the core of substance abuse is a failure to exercise self control

10. My feelings of disapproval of substance abusers get in the way of my ability to empathize with them

11. I can make a great difference in the lives of my patients who abuse drugs

12. People who abuse drugs have a special ability to manipulate physicians

13. Treatment is effective and worth the effort

$\square$

\begin{tabular}{l|l|l|l}
$\square_{1}$ & $\square_{2}$ & $\square_{3}$ & $\square_{4}$ \\
$\square_{1}$ & $\square_{2}$ & $\square_{3}$ & $\square_{4}$
\end{tabular}

Strongly

Agree

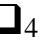

$\square_{4}$

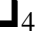

\begin{tabular}{ll|l|l}
$\square_{1}$ & $\square_{2}$ & $\square_{3}$ & $\square_{4}$
\end{tabular}

$\begin{array}{llll}\square_{1} & \square_{2} & \square_{3} & \square_{4}\end{array}$

\begin{tabular}{|c|c|}
\hline$\square_{2}$ & $\square_{3}$ \\
\hline$\square_{2}$ & $\square_{3}$ \\
\hline
\end{tabular}

\begin{tabular}{ll|l|l}
$\square_{1}$ & $\square_{2}$ & $\square_{3}$ & $\square_{4}$
\end{tabular}

\begin{tabular}{l|l|l|l}
$\square_{1}$ & $\square_{2}$ & $\square_{3}$ & $\square_{4}$
\end{tabular}

\begin{tabular}{ll|l|l}
$\square_{1}$ & $\square_{2}$ & $\square_{3}$ & $\square_{4}$
\end{tabular}

$\begin{array}{lll}\square_{1} & \square_{3}\end{array}$

$\square_{4}$ 


\section{Pre-Survey 2 for Medical Students}

\section{Additional Questions}

1. Have you ever attended a 12-Step meeting as either a participant or an observer?

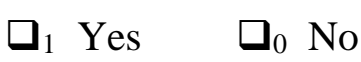

2. If your answer to Question IV.1 is "Yes," were you required to observe a 12step meeting as part of a medical school course (Skip this question if your $\square_{1}$ Yes $\square_{0}$ No answer to Question IV.1 is "No")?

3. Do you have a history of past or current substance abuse or dependence (alcohol or other drugs [excluding nicotine]) OR do you have a close friend or family

$\square_{1}$ Yes $\square_{0}$ No member or colleague with such a history?

4. Some physicians have negative attitudes towards patients with substance use disorders. What do you think are the sources of those attitudes? (Number each source below from 1-5 where "1" signifies the most important source of the negative attitude, " 2 " the 2 nd most important source, and so on; use each number only once)
a. Negative experiences with patients with substance use disorders
b. Substance use by self, family member or close friend

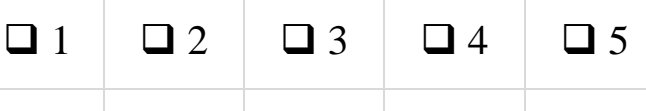
c. Attending physicians with negative attitudes

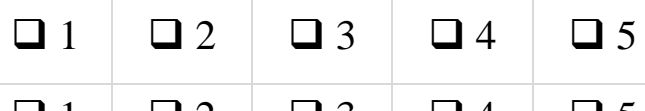
d. Resident physicians with negative attitudes

\begin{tabular}{|l|l|l|l|l}
$\square 1$ & $\square 2$ & $\square 3$ & $\square 4$ & $\square 5$ \\
$\square 1$ & $\square 2$ & $\square 3$ & $\square 4$ & $\square 5$
\end{tabular}
e. Non-physician health care professionals, e.g., nurses, with negative attitudes

\begin{tabular}{ll|l|l|l}
$\square 1$ & $\square 2$ & $\square 3$ & $\square 4$ & $\square 5$
\end{tabular}

5. Some physicians have positive attitudes towards patients with substance use disorders. What do you think are the sources of those attitudes? (Number each source below from 1-5 where "1" signifies the most important source of the positive attitude, "2" the 2 nd most important source, and so on; use each number only once)

\begin{tabular}{|l|l|l|l|l|l|l|}
\hline a. $\begin{array}{l}\text { Positive experience with patients with } \\
\text { substance use disorders }\end{array}$ & $\square 1$ & $\square 2$ & $\square 3$ & $\square 4$ & $\square 5$ \\
\hline b. $\quad \begin{array}{l}\text { Substance use by self, family member or close } \\
\text { friend }\end{array}$ & $\square 1$ & $\square 2$ & $\square 3$ & $\square 4$ & $\square 5$ \\
\hline c. $\quad$ Attending physicians with positive attitudes & $\square 1$ & $\square 2$ & $\square 3$ & $\square 4$ & $\square 5$ \\
\hline d. & Resident physicians with positive attitudes & $\square 1$ & $\square 2$ & $\square 3$ & $\square 4$ & $\square 5$ \\
\hline e. & $\begin{array}{l}\text { Non-physician health care professionals, e.g., } \\
\text { nurses, with positive attitudes }\end{array}$ & $\square 1$ & $\square 2$ & $\square 3$ & $\square 4$ & $\square 5$ \\
\hline
\end{tabular}




\section{Pre-Survey 2 for Medical Students}

V. Jefferson Scale of Physician Empathy (JSPE)*.Instructions: Please indicate the extent of your agreement or disagreement with each of the following statements by checking the box with the appropriate rating. Please use the following 7-point scale (a higher number on the scale

indicates more agreement).

\section{0------1-------2------3-------4-------5------6 \\ Strongly Disagree \\ Strongly Agree}

Strongly

Strongly

Disagree

Agree

1. Physicians' understanding of their patients' feelings and the feelings of their patients' families does not influence<smiles></smiles><smiles>[AlH2]</smiles><smiles>[131In]</smiles><smiles>[GeH3]</smiles>
medical or surgical treatment.

2. Patients feel better when their physicians understand their feelings.

3. It is difficult for a physician to view things from patients' perspectives.

4. Understanding body language is as important as verbal communication in physician-patient relationships.

5. A physician's sense of humor contributes to a better clinical outcome.

6. Because people are different, it is difficult to see things from patients' perspectives.

7. Attention to patients' emotions is not important in history taking.

8. Attentiveness to patients' personal experiences does not influence treatment outcomes.

9. Physicians should try to stand in their patients' shoes when providing care to them.

10. Patients value a physician's understanding of their feelings which is therapeutic in its own right.

11. Patients' illnesses can be cured only by medical or surgical treatment; therefore, physicians' emotional ties with their patients do not have a significant influence in medical or surgical treatment. 


\section{Pre-Survey 2 for Medical Students}

\section{Strongly \\ Disagree}

12. Asking patients about what is happening in their personal lives is not helpful in understanding their physical complaints.

13. Physicians should try to understand what is going on in their patients' minds by paying attention to their non-verbal cues and body language.

14. I believe that emotion has no place in the treatment of medical illness.

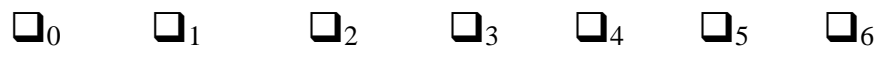

15. Empathy is a therapeutic skill without which the physician's success is limited.

16. Physicians' understanding of the emotional status of their patients and their families is one important component of the physician-patient relationship.

17. Physicians should try to think like their patients in order to render better care.

18. Physicians should not allow themselves to be influenced by strong personal bonds between their patients and their family members.

19. I do not enjoy reading non-medical literature or the arts.

20. I believe that empathy is an important therapeutic factor in medical treatment.

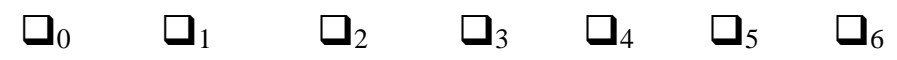

*Used with permission from Jefferson Medical College. All rights reserved.

By checking this box, I refuse permission to allow my results to be used for research purposes: 


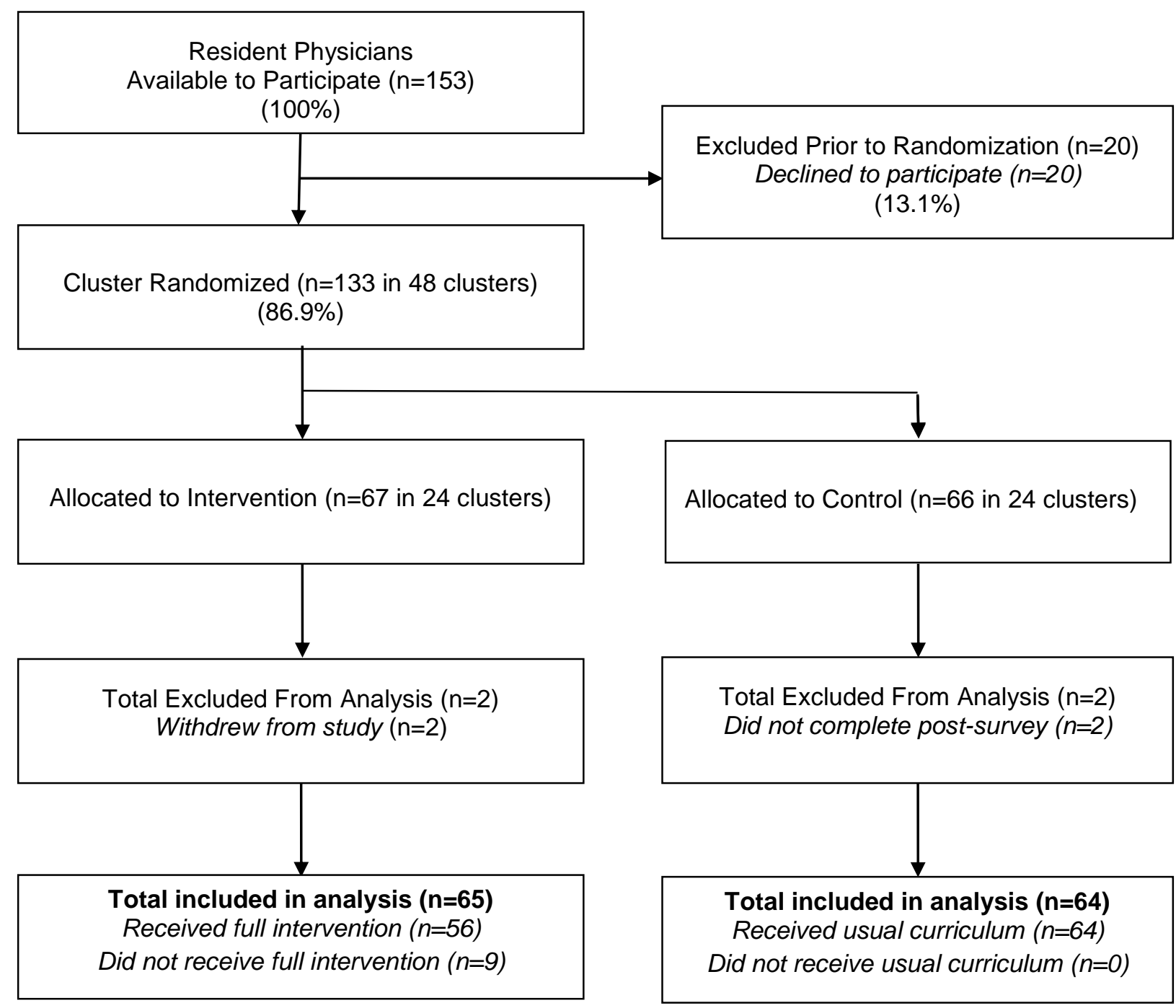

Supplemental Digital Figure 1 Modified CONSORT* flow diagram of study population of resident physicians. From August 2011 to June 2012, all residents who were on the same outpatient rotation during the same time period at the same qualifying clinical site and who gave informed consent were randomized as a cluster to intervention or control group. See Methods for details. *Modified from http://www.consort-statement.org/consort-statement/flow-diagram0/. 


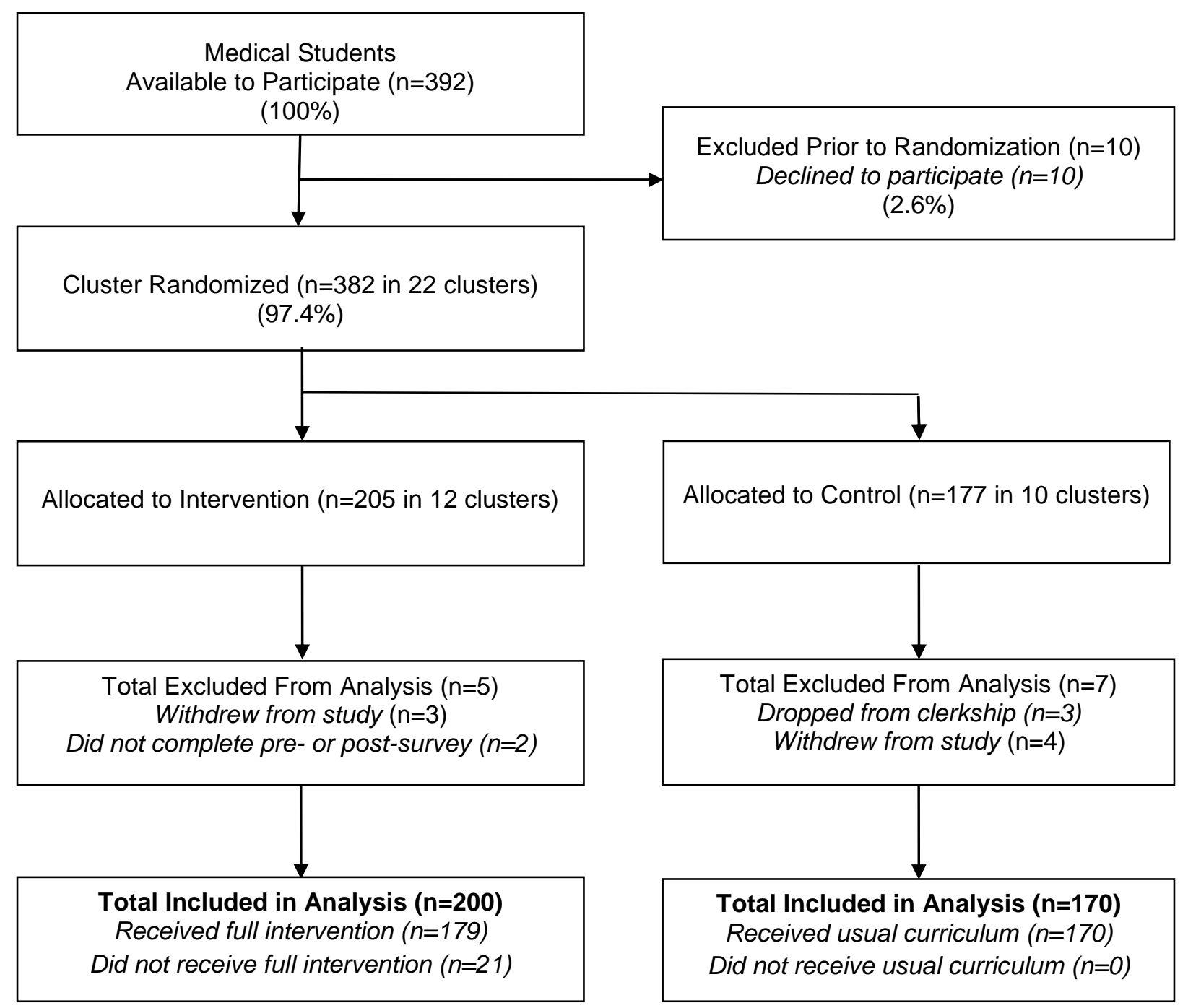

Supplemental Digital Figure 2 Modified CONSORT* flow diagram of study population

of medical students. From August 2011 to June 2012, all medical students who were on the same family medicine clerkship at the Perelman School of Medicine or on the same Ambulatory Block of the Internal Medicine clerkship block at Drexel University College of Medicine during the same time period and who gave informed consent were randomized as a cluster to intervention or control group. See Methods for details. *Modified from http://www.consort-

statement.org/consort-statement/flow-diagram0/ 


\section{Supplemental Digital Table 1}

Table of 7 Survey Factors Used as Outcome Variables and their Associated Survey Items with Factor Loading

\begin{tabular}{|c|c|c|c|}
\hline $\begin{array}{c}\text { Factor } \\
\quad \#\end{array}$ & $\begin{array}{l}\text { Factor Name } \\
\text { (Abbreviated) }\end{array}$ & $\begin{array}{l}\text { Number of } \\
\text { Associated } \\
\text { Items in } \\
\text { Factor }\end{array}$ & $\begin{array}{l}\text { Associated Items (Identified by Survey } \\
\text { Section and Item Number) with Factor } \\
\text { Loading*+† }\end{array}$ \\
\hline 1 & $\begin{array}{c}\text { View of Patient's } \\
\text { Personal Characteristics }\end{array}$ & 8 & $\begin{array}{c}\text { Section III: Items } \\
1(.693), 4(.691), 5(.664), 6(.632), 7 \\
(.548), 9(.527), 10(.518), 12(.295)\end{array}$ \\
\hline 2 & $\begin{array}{l}\text { Treatment Efficacy } \\
\text { Basic }\end{array}$ & 4 & $\begin{array}{c}\text { Section III: Items } \\
2(.739), 3(.736), 8(.532), 11(.496)\end{array}$ \\
\hline 3 & $\begin{array}{c}\text { Importance of Screening } \\
\text { and Counseling) }\end{array}$ & 2 & $\begin{array}{l}\text { Section IIA: Items } \\
3(.906), 4(.901)\end{array}$ \\
\hline 4 & $\begin{array}{l}\text { Confidence: Able to } \\
\text { Make a Difference }\end{array}$ & 4 & $\begin{array}{c}\text { Section IIA: Items } \\
8 \mathrm{a}(.899), 8 \mathrm{~b}(.932), 8 \mathrm{c}(.888), 8 \mathrm{~d}(.868)\end{array}$ \\
\hline 5 & $\begin{array}{l}\text { Confidence: Ability, } \\
\text { Knowledge and Skills }\end{array}$ & 3 & $\begin{array}{c}\text { Section IIA: Items } \\
5(.515), 6(.604), 7(.566)\end{array}$ \\
\hline 6 & $\begin{array}{c}\text { Prepared to Discuss and } \\
\text { Counsel re Tobacco or } \\
\text { Alcohol } \\
\end{array}$ & 4 & $\begin{array}{c}\text { Section IIA: Items } \\
1 \mathrm{a}(.822), 1 \mathrm{~b}(.775), 2 \mathrm{a}(.696), 2 \mathrm{~b}(.61)\end{array}$ \\
\hline 7 & $\begin{array}{l}\text { Prepared to Discuss and } \\
\text { Counsel re Prescription } \\
\text { or Illicit Drugs }\end{array}$ & 5 & $\begin{array}{c}\text { Section IIA: Items } \\
1 \mathrm{c}(.794), 1 \mathrm{~d}(.71), 2 \mathrm{c}(.799), 2 \mathrm{~d}(.722), \\
2 \mathrm{e}(.599)\end{array}$ \\
\hline
\end{tabular}

*See complete surveys for wording of items that are identified by their survey sections and item numbers (Supplementary Digital Content Appendix 1 or 5).

$\dagger$ Factor loading for each item is in parentheses following the item. See Methods for details of factor analyses.

\$Factor analysis of Section II identified Factors 3-7. This analysis also identified an $8^{\text {th }}$ factor that consisted of 10 items (Items B1-B6 and C1-C4 in Section II of the survey [SDC Appendix 1]). We decided a priori not to use this factor as a primary outcome since we did not expect responses to a majority of the items in this factor to change due to the intervention. 


\section{Supplemental Digital Table 2}

Resident Physicians Who Were Enrolled in Study from August 2011 to June 2012: Baseline Characteristics of Study Population in Intervention and Control Groups* ${ }^{*}$

\begin{tabular}{|c|c|c|c|}
\hline Variable & Intervention Group & Control Group & P value \\
\hline Number in Analysis & 65 & 64 & NA \\
\hline Affiliation (\%PSOM) & 63.1 & 64.1 & 0.91 \\
\hline Gender (\%Male) & 52.3 & 53.1 & 0.93 \\
\hline Age (Years) & $29.1(2.48)$ & $29.8(4.11)$ & 0.24 \\
\hline $\begin{array}{c}\text { Ethnicity } \\
\text { (\%Hispanic/Latino) }\end{array}$ & 0 & 1.6 & 0.50 \\
\hline \multicolumn{4}{|l|}{ Race (\% Total) } \\
\hline $\begin{array}{c}\text { American Indian/Alaska } \\
\text { Native }\end{array}$ & 0 & 0 & 1.00 \\
\hline Asian & 30.8 & 43.8 & 0.13 \\
\hline African American & 7.7 & 1.6 & 0.21 \\
\hline $\begin{array}{l}\text { Native Hawaiian/Pacific } \\
\text { Islander }\end{array}$ & 0 & 0 & 1.00 \\
\hline Caucasian & 63.1 & 54.7 & 0.33 \\
\hline Year of Training $(\%)$ & & & 0.89 \\
\hline PGY1 & 18.5 & 14.8 & \\
\hline PGY2 & 52.3 & 55.7 & \\
\hline PGY3 & 26.2 & 27.9 & \\
\hline PGY4 & 3.1 & 1.6 & \\
\hline Residency Program (\%) & & & 0.77 \\
\hline Family Medicine & 9.2 & 12.7 & \\
\hline $\begin{array}{l}\text { Internal Medicine (non- } \\
\text { Primary Care track) }\end{array}$ & 76.9 & 69.8 & \\
\hline Internal Medicine-Pediatrics & 4.6 & 7.9 & \\
\hline
\end{tabular}




\begin{tabular}{|c|c|c|c|}
\hline $\begin{array}{c}\text { Internal Medicine (Primary } \\
\text { Care track) }\end{array}$ & 9.2 & 9.5 & \\
\hline $\begin{array}{c}\text { Career Plans within Internal } \\
\text { Medicine (non-Primary } \\
\text { Care track) (\%) }\end{array}$ & & & 0.60 \\
\hline Primary Care & 9.4 & 4.4 & \\
\hline Undecided & 17.0 & 19.6 & \\
\hline Specialty & 73.6 & 76.1 & 0.18 \\
\hline $\begin{array}{c}\text { Medical School: Hours of } \\
\text { Substance Abuse Classes } \\
(\%)\end{array}$ & & & \\
\hline None & 0 & & \\
\hline $1-3$ & 23.1 & 4.8 & \\
\hline $4-9$ & 44.6 & 45.2 & \\
\hline $10-25$ & 10.8 & 24.2 & \\
\hline$>25$ & & 3.2 & \\
\hline & & & \\
\hline Residency: Hours of & & & \\
\hline Substance Abuse Classes & 10.8 & 17.7 & \\
\hline None & 27.7 & 21.0 & \\
\hline $1-3$ & 10.8 & 1.6 & \\
\hline $4-9$ & 1.5 & 0 & \\
\hline $10-25$ & & & \\
\hline$>25$ & & & \\
\hline
\end{tabular}

Abbreviations: PSOM, Perelman School of Medicine at the University of Pennsylvania; PGY1, Post-Graduate Year 1; PGY2, Post-Graduate Year 2; PGY3, Post-Graduate Year 3; PGY4, PostGraduate Year 4.

*Includes resident physicians of post-graduate years 1-4 in internal medicine programs (categorical, primary care, and medicine-pediatrics) and family medicine programs affiliated with Perelman School of Medicine, University of Pennsylvania and College of Medicine, Drexel University, who met enrollment criteria (see Methods for details).

$\dagger$ Means (with standard deviations) or percent frequencies

\$1) Contrasts of continuous measures based on independent sample t-test. 2) Binary measures contrast based on Chi-square test. 3) Fisher's exact test for assessment of ethnicity. 4) Each race contrast based on specific classification versus others. 5) Categorical measures contrast based on Chi-square test with the exception of number of hours of substance abuse classes for which a Mantel-Haenszel statistic was used to accommodate the ordinality of the Likert Scale. 


\section{Supplemental Digital Table 3}

Medical Students Who Were Enrolled in Study from August 2011 to June 2012: Baseline Characteristics of Study Population in Intervention and Control Groups* ${ }^{*}$

\begin{tabular}{|c|c|c|c|}
\hline Variable & $\begin{array}{l}\text { Intervention } \\
\text { Group }\end{array}$ & Control Group & $\begin{array}{c}\text { Statistical } \\
\text { Significance }\end{array}$ \\
\hline Number in Analysis & 200 & 170 & NA \\
\hline Affiliation (\%PSOM) & 41.5 & 41.2 & 0.95 \\
\hline Gender (\%Male) & 47.0 & 48.8 & 0.73 \\
\hline Age (Years) & $25.8(2.58)$ & $25.7(2.63)$ & 0.98 \\
\hline $\begin{array}{c}\text { Ethnicity } \\
\text { (\%Hispanic/Latino) }\end{array}$ & 7.5 & 4.1 & 0.17 \\
\hline \multicolumn{4}{|l|}{ Race (\%Total) } \\
\hline $\begin{array}{c}\text { American Indian/Alaskan } \\
\text { Native }\end{array}$ & 0.5 & 0.6 & 1.00 \\
\hline Asian & 26.0 & 31.4 & 0.26 \\
\hline African American & 5.5 & 7.1 & 0.53 \\
\hline $\begin{array}{l}\text { Native Hawaiian/Pacific } \\
\text { Islander }\end{array}$ & 0 & 0.6 & 1.00 \\
\hline Caucasian & 72.5 & 63.3 & 0.06 \\
\hline Year of Training $(\%)$ & & & 0.01 \\
\hline MS1 & 0 & 0 & \\
\hline MS2§ & 28.5 & 17.1 & \\
\hline MS3 & 71.5 & 82.4 & \\
\hline MS4 & 0 & 0.6 & \\
\hline & & & \\
\hline Future Career Plans (\%) & & & 0.27 \\
\hline Primary Care & 10.5 & 10.0 & \\
\hline Undecided & 57.5 & 65.3 & \\
\hline Specialty & 32.0 & 24.7 & \\
\hline
\end{tabular}




\begin{tabular}{|c|c|c|c|}
\hline $\begin{array}{c}\text { Medical School: Hours of } \\
\text { Substance Abuse Classes } \\
(\%)\end{array}$ & & & 0 \\
\hline None & 0.5 & 0.28 & \\
\hline $1-3$ & 13.0 & 10.2 & \\
\hline $4-9$ & 44.6 & 43.7 & \\
\hline $10-25$ & 32.0 & 31.7 & \\
\hline$>25$ & 10.0 & 13.8 & \\
\hline & & & \\
\hline $\begin{array}{c}\text { Number of Patients with } \\
\text { Substance Abuse }\end{array}$ & & & \\
\hline Encountered (\%) & 2.0 & 2.4 & \\
\hline None & 17.0 & 21.6 & \\
\hline $1-3$ & 27.0 & 27.5 & \\
\hline $4-9$ & 33.0 & 24.6 & \\
\hline $10-25$ & 21.0 & 24.0 & \\
\hline$>25$ & & & \\
\hline
\end{tabular}

Abbreviations: PSOM, Perelman School of Medicine at the University of Pennsylvania; MS1, first year medical student; MS2, second year medical student; MS3, third year medical student; MS4, fourth year medical student.

*Includes medical students who were in years 2 or 3 in Perelman School of Medicine at the University of Pennsylvania and who were on the family medicine clerkship or who were in year 3 in Drexel University College of Medicine and who were on the ambulatory rotation of the internal medicine block (clerkship).

$\dagger$ Means (with standard deviations) or percent frequencies

\$1) Contrasts of continuous measures based on independent sample t-test. 2) Binary measures contrast based on Chi-square test. 3) Fisher's exact test for assessment of Ethnicity. 4) Each Race contrast based on specific classification versus others. 5) Categorical measures contrast based on Chi-square test with the exception of Number of Hours of Substance Abuse Classes for which a Mantel-Haenszel statistic was used to accommodate the ordinality of the Likert Scale.

$\S$ Having a greater percentage of MS2s in the I-group was expected due to having three I-group clusters (vs. two C-group clusters) at Penn during the first 5 months of the study when MS2s at Penn were on their clerkships. 